\title{
Assessment of Efforts at Expanding Financial Inclusion in Nigeria
}

\section{Clement Chiahemba Ajekwe}

Department of Accounting, Faculty of Management Sciences, Benue State University, Makurdi, Nigeria

Email address:

cajekwe@bsum.edu.ng

\section{To cite this article:}

Clement Chiahemba Ajekwe. Assessment of Efforts at Expanding Financial Inclusion in Nigeria. International Journal of Economics, Finance and Management Sciences. Special Issue: Financial Inclusion and Challenges Ahead. Vol. 8, No. 5, 2020, pp. $180-187$. doi: 10.11648/j.ijefm.20200805.12

Received: November 26, 2019; Accepted: April 7, 2020; Published: September 8, 2020

\begin{abstract}
The Central Bank of Nigeria (CBN), in October 2012, crafted a National Financial Inclusion Strategy (NFIS) for achieving $80 \%$ overall financial inclusion by year 2020 from the base line figure of $46.3 \%$ in 2010 . The CBN refreshed/revised the 2012 NFIS in 2018 to address changes in the regulatory and financial technology landscape with a view to accelerate achievement of the strategic objective of 80 per cent financial inclusion by the year 2020 . This paper reviews relevant literature to assess efforts at expanding financial inclusion through the strategy encapsulated in NFIS (2018). Data was gathered from published sources (Enhancing Financial Innovation and Access in Nigeria Survey reports, World Bank Global Findex reports, the Central Bank of Nigeria; Interswitch \& Nigeria Inter-Bank Settlement System annual reports) as well as supply-side data derived from statutory returns submitted by financial service providers to their respective regulatory agencies. Evidence from the study show that 2018 financial inclusion targets (products, channels, enablers, financial literacy \& other initiatives for youth and gender inclusion) fell short of expectations, indicating that the 2020 targets are unlikely to be met. This study recommends that the identified critical challenges militating against financial inclusion expansion should be addressed. In particular, financial education among all stakeholders in the financial inclusion process should be instituted more purposively.
\end{abstract}

Keywords: Financial Inclusion, Financial Inclusion Strategy, Financial Inclusion Assessment, Nigeria

\section{Introduction}

Interest in financial inclusion comes from the potential it holds as an instrument for inclusive growth and economic development, particularly in the aspects of employment generation, poverty reduction, wealth creation, improvement in welfare and general standard of living [1]. Financial inclusion is also at the heart of at least ten of the 17 United Nation's 2030 Sustainable Development Goals (SDGs). Indeed, there is evidence to show that whatever the financial access model; South Africa's Mzansi [2]; Brazil's banking correspondents [3, 4], Kenya's M-PESA \& M-KESHO [5] India's Microfinance system, etc, financial inclusion supports overall economic growth and the achievement of broader development goals (https://www.uncdf.org/uncdf-and-thesdgs).

Benefits of increased access to finance at the macroeconomic level are potentially enormous: McKinsey Global Institute (MGI) [6] documents the potential economic benefits of access to digital financial services alone to Nigeria to include (a) Bringing 46 million new individuals into the formal financial system; (b) Boosting GDP growth by $12.4 \%$ (USD 88 billion) by 2025; (c) Attracting new deposits worth USD 36 billion; (d) Providing new credit worth USD 57 billion; (e) Creating 3 million new jobs; (f) Reducing leakages in government's financial management annually by USD 2 billion [6]. Given these positive effects of increased access to finance relative to economic recovery and growth, building an inclusive financial system is an important objective for policymakers worldwide, including Nigeria. Realisations that financial inclusion helps improve household welfare and spur small enterprise activity, among other benefits, is the reasoning behind the World Bank's ambitious goal of Universal Financial Access (UFA) for all by the year 2020 [7]. Economies with deeper financial intermediation tend to grow faster and reduce income inequality [8].

The Central Bank of Nigeria (CBN), in October 2012, 
crafted a National Financial Inclusion Strategy (NFIS) for achieving $80 \%$ overall financial inclusion (i.e., easily accessing a broad range of formal financial services that meet their needs at affordable costs) by year 2020 from the base line figure of $46.3 \%$ in 2010 . Complimentary to the NFIS [9], the CBN introduced a "cash-less Nigeria policy" aimed at reducing the amount of physical cash (coins and notes) circulating in the economy and encouraging more electronicbased transactions; making payments over the internet, at unmanned vending machines or at manned points of sale (POS) using mobile devices, personal digital assistants (PDA), smart cards and other electronic payment systems, including debit and credit cards thereby driving financial inclusion by providing more efficient transaction options and greater reach. Under the policy, bank customers are to pay cash handling charges for daily cash deposit and withdrawal in excess of $\$ 150,000$ for individuals and $\$ 1$ million for corporations. (These amounts were later reviewed upward to five hundred thousand naira $(\$ 500,000)$ and three million naira ( $\$ 3$ milion) for individuals and corporate organizations respectively). Under a cashless economy, electronic payments/receipts act as the leverage for financial inclusion [10-14]. Not only has a clear positive correlation being established between the proportion of electronic transactions and the proportion of the financially included [15], evidence abound that attaining high levels of financial inclusion requires aggressive policies that promote cashless societies [16-20].

This paper assesses the current status of financial inclusion in the Nigerian economy and tracks progress in achieving financial inclusion targets as encapsulated the NFIS and seeks to answer the question: how has Nigeria's financial inclusion targets fared so far? The paper is organised as follows: Section 2 explains the concept of financial inclusion, while theories that have been used to analyse financial inclusion are considered in section 3 , followed in section 4 by a review of financial inclusion empirical literature. Section 5 assesses progress towards achievement of financial inclusion targets. Section 6 discusses issues in financial inclusion in Nigeria and section 7 concludes and provides recommendations for further action.

\section{Concept of Financial Inclusion}

Financial inclusion refers to a world where everyone, wherever they live, has access and can use the financial products and services needed to capture opportunities and reduce vulnerability [1]. Financial inclusion originated as a solution to financial exclusion of low income individuals and/or areas from the banking system. Banks preferred to transact exclusively with "high net worth" individuals who are more visibly likely to offer the financial institutions higher profit opportunities [21] than with low income individuals. Following from this, financial inclusion will be understood to mean the creation of financial sector policies that compel making banking services accessible to all [22, 23]. In addition, financial inclusion not only aims at providing access to banking services, it also creates monetary opportunities aimed at reducing social inequality and poverty [24]. Therefore, access to financial services allows all, including the poor, to save money outside the house, and helps in mitigating the risks that the poor face as a result of economic shocks such as economic reversals occasioned by unexpected circumstances $[25,26]$. Thus financial inclusion is created through the uptake and use of individual accounts with institutions that offer a full suite of financial services savings, credit, money transfers, insurance and investment. Full-service financial institutions include banks, mobile money service providers, and nonbank financial institutions, such as deposit-taking microfinance banks (MFBs) and financial cooperatives (http://www.finclusion.org/). In the era of ubiquitous availability of information and communication technology (ICT) and financial technology (fintech), the term "digital financial inclusion" is often used to mean providing people with digital financial services. Digital financial inclusion, denotes bringing every individual and every institution to a digital platform where financial transactions for the payment for goods and services are done electronically through various electronic channels that are safe and secure and evidenced in useful and affordable banking products and services that meet people's needs, transactions, payments, savings, credit and insurance, delivered responsibly and in a sustainable way.

\section{Theories of Financial Inclusion}

Buckland [27] highlights two broad categories of theories that have been used to analyze financial inclusion/exclusion economic (i.e., neoclassical economic theory and newKeynesian theory) and interdisciplinary theories (i.e., behavioural economics, institutional theories, politicaleconomy theories, poverty and community-based analyses, geographic spatial analyses, and household economy). The neo-classical theory concentrates on economic agents; firms and consumers whose behaviours are assumed to be rational, self-interested, well-informed and competitive. With these assumptions, the neo-classical theory concludes that financial inclusion/exclusion is the result of consumer choice and/or government policy. As far as consumer choice is concerned, it is possible for the consumer to use informal financial services instead of mainstream markets, for whatever reason, which can limit financial access. It is also possible that government policy may create distortions in credit markets that further lead to exclusion of the financially disadvantaged. New-Keynesian theory emphasises market distortions embedded in the micro-economy such as information asymmetries. In relation to financial inclusion/exclusion, it relates to the notion of credit constraints. Stiglitz and Weiss [28] provide a compelling explanation on this issue by shedding light on the effect of imperfect information about borrowers on credit exclusion, whereby creditors tend to depress interest rates and restrict credit in order to avoid risky borrowers. This alarming problem further reinforces income and asset inequality i.e., 
credit markets are no longer unified (if ever they were), but instead are fragmented and diverse; and financial exclusion grows as a result of wealth/income and security/insecurity disparities [29].

Financial inclusion/exclusion is interdisciplinary in nature; insights can be learned from more than one discipline including institutional theory, political economy and povertyand-community analyses [27]. Each of these theories has been influenced by more than one discipline; economics, sociology, psychology as well as geography. Other interdisciplinary theories are poverty and community analysis, geographic spatial analysis and household economy. Community-based analyses highlight the realities and experiences of the financially excluded by understanding the structures that reinforce inequality and poverty. Results show that low-income consumers usually behave in highly rational ways according to the relative costs and benefits of the variety types of financial services [30]. Both economic and interdisciplinary theories have influenced analyses in this study.

\section{Empirical Studies}

Panel and cross section empirical studies grounded in institutional theory and based in several countries [31-37] have concluded that financial inclusion plays a vital role in raising a strong and well-organized structure of the financial system which enhances the growth rate of the economy. Demirguc-Kunt and Klapper [32] explained how income levels increase rapidly in the countries in which bank branches as well as deposit are high; this indicates that higher financial inclusion levels boost high growth in these economies. Balach et al [33] measured financial inclusion in terms of commercial bank branches per 100,000 adults and ATMs per 100,000 adults; results from this study confirmed a significant positive effect of financial inclusion on economic growth. Likewise, Sethi and Acharya [38] assessed the link between financial inclusions on the economic growth for 31 countries and concluded that, financial inclusion encouraged economic growth for these countries.

Similarly, individual country level association studies have also showed that financial inclusion as evidenced by institutional indicators in banking including, commercial bank branches, credit, and availability of ATMs have been demonstrated to be veritable predictors that spur economic growth [39, 40]. Babajide, Adegboye and Omankhanlen [41]) investigated financial inclusion: "the process that marks improvement in quantity, quality, and efficiency of financial intermediary services" on economic growth of Nigeria. Proxies employed by Babajide et al. [41] for financial inclusion (FI) included the number of commercial bank branches per $1000 \mathrm{~km}^{2}$ and per 100,000 adults and commercial bank deposits; the results were that FI is a significant determinant of the total factors of production, as well as capital per worker, which invariably determines the final level of output in the economy.

Similarly, Omojolaibi [42]) enquired into the impact of financial inclusion and governance characteristics on economic progress via three major channels: investment in infrastructure, per capita GDP and income inequality. Three striking results were reported from this study: (i) financial inclusion and governance indices have statistical relevance in determining infrastructural investment in Nigeria; (ii) Governance indices and commercial bank deposit significantly increase per capita GDP; and (iii) financial inclusion has the tendency to bridge the gap between the rich and the poor and reduce the prevalence of poverty in the economy. These findings lend credence to a policy of addressing financial exclusion of low-income groups from financial services in order to reduce income inequality and increase per capita GDP.

From their study, Migap, Okwanya and Ojeka [40] demonstrated how access to basic financial services in Nigeria would lead to increased economic activities and employment opportunities for rural households. They concluded that as more people get engaged in economic activities, the disposable income of the rural household would rise, leading to more savings and a robust deposit base for the bank, suggesting that the resultant multiplier effect would lead to inclusive economic growth. These studies demonstrate that financial inclusion is central to a country's economic growth and development

\section{How Nigeria's Financial Inclusion Targets Have Fared so Far}

In 2018, the Central Bank of Nigeria refreshed/revised its 2012 National Financial Inclusion Strategy to address changes in the regulatory and technology landscape with a view to accelerate achievement of the strategic objective of 80 per cent financial inclusion by the year 2020. The core of the Revised National Financial Inclusion Strategy [9] focused on a first principle approach with two overarching principles; creating a level playing ground and adopting a risk-based approach and encouraging stakeholders to play in the area of their core strength or comparative advantage. The strategy also seeks to leverage Digital Financial Services (DFS) to drive financial inclusion by enabling Digital ID, expanding agent network, focusing on business cases that would drive Government to People (G2P) and People to Government (P2G) payment amongst other priority areas. The major goal of NFIS [9] remains reducing the proportion of financially excluded adult Nigerians to $20 \%$ in year 2020 from the baseline figure of $46.3 \%$ in 2010 . The strategy stipulates that $70 \%$ of those to be included in the financial system by 2020 should be in the formal sector; specific products, channels and enabler targets are as shown in Table 1.

By 2016, a total of 40.1 million adult Nigerians (i.e., $41.6 \%$ of the adult population) were financially excluded. Further analysis (in 2016) revealed that $55.1 \%$ of the excluded population were women, $61.4 \%$ of the excluded population were young (within the ages of 18 and 35 years), $34.0 \%$ had no formal education and $80.4 \%$ resided in rural 
areas and /or in the northern regions of the country. To address these situations, the NFIS [9] refocused strategy to explore five priority themes of Youth, Women, Rural areas, Micro Small and Medium Enterprises (MSMEs) and the Northern regions of the country. These priority areas are expected to close identified gaps and tremendously advance financial inclusion and increase the proportion of financially included adult Nigerians to $80 \%$ in year 2020 .

Actual financial inclusion performance is presented in three sub-headings: Products, Channels and Enablers. Table 1 presents quantitative measures of implementation progress relative to products (payments, savings, credit, insurance and pension), channels (bank branches, ATMs, POS \& Agents) and enablers (KYC/ID, financial literacy \& youth and women initiatives). Table 1 is based on data from EFInA [15], the World Bank's Global Findex Survey Report [43], the Central Bank of Nigeria [9], Interswitch [44] and NIBSS [45] as well as supply-side data derived from statutory returns submitted by service providers to their respective regulatory agencies.

Table 1. Status of Financial Inclusion in Nigeria.

\begin{tabular}{|c|c|c|c|c|c|c|c|c|c|}
\hline & \multicolumn{9}{|l|}{ Status of Financial Inclusion in Nigeria } \\
\hline & & 2016 & & 2017 & & 2018 & & 2020 & Variance \\
\hline & & 1 & 2 & 3 & 4 & 5 & 6 & 7 & 8 \\
\hline & & Target & Actual & Target & Actual & Target & Actual & Target & $(6-7)$ \\
\hline \multirow{6}{*}{$\begin{array}{l}\% \text { of Total } \\
\text { Adult } \\
\text { Population }\end{array}$} & Formal and Informal Financial inclusion & & $58.4 \%$ & & & & $63.3 \%$ & $80 \%$ & \\
\hline & Payment with BVN & $56 \%$ & $28 \%$ & $59.8 \%$ & $31.3 \%$ & $63.2 \%$ & $36.2 \%$ & $70 \%$ & $-33.8 \%$ \\
\hline & Savings (BVN) & $46 \%$ & $28 \%$ & $49.2 \%$ & $31.3 \%$ & $52.8 \%$ & $36.2 \%$ & $60 \%$ & $-23.8 \%$ \\
\hline & Credit through regulated financial institutions & $29 \%$ & $1.8 \%$ & $31.6 \%$ & $5.4 \%$ & $34.4 \%$ & $5.5 \%$ & $40 \%$ & $-34.5 \%$ \\
\hline & Regulated pension schemes & $26 \%$ & $7.9 \%$ & $29.2 \%$ & $8.4 \%$ & $32.4 \%$ & $8.5 \%$ & $40 \%$ & $-31.5 \%$ \\
\hline & DMB Branches & 7.5 & 5.6 & 7.5 & 5.5 & 7.5 & 4.8 & 7.6 & -2.8 \\
\hline Units per & $\mathrm{MFB}^{7}$ Branches & 4.6 & 2.3 & 4.7 & 2.3 & 4.7 & 0.9 & 5.0 & -4.1 \\
\hline 100,000 & ATMs & 46.2 & 18.0 & 49.5 & 18.2 & 49.5 & 19.0 & 59.6 & -40.6 \\
\hline \multirow[t]{2}{*}{ adults } & POS & 524.1 & 116.3 & 605.6 & 153.0 & 605.6 & 218 & 850.0 & -632 \\
\hline & Mobile Money/Bank agents & 37.2 & 18.8 & 43.4 & 28.2 & 43.4 & 38.6 & 62.0 & +23.4 \\
\hline$\%$ of Adult & KYC- Tier 1 ID & 67 & $60.4 \%$ & $75.4 \%$ & NA. & NA & NA & $100 \%$ & $-40 \%$ \\
\hline
\end{tabular}

Source: National Financial Inclusion Strategy (Revised), 2018; EFInA (2018); Global Findex Survey Report (2018); Central Bank of Nigeria (2018); Interswitch (2018); NIBSS (2018)

\subsection{Products}

\subsubsection{Electronic Payments}

The proportion of adults who owned a regulated financial product that can be used for electronic payment rose to $36.2 \%$ (36.1 million adults) from 31.3\% (31.0 million adults) in 2017. The actual volume and value of electronic transactions was 217 million and 13.7 trillion respectively which is an increase of $10 \%$ and $15 \%$ respectively over the 2017 figures. Further analysis reveals the highest volumes of transactions were done mostly through Point of Sale (POS) transactions, Automated Teller Machines (ATMs), NIBSS Instant Payment (NIP), Electronic Bill Payments (E-Bills), Mobile Money and Web Payments. However despite significant progress made, the 2018 electronic payments target of $63.2 \%$ were missed.

\subsubsection{Savings}

The proportion of adults who owned savings products increased to $36.2 \%$ in 2018 (36.1 million) from 31.3\% (31.0 million) in 2017. As at December 2018, the banking industry reported a total of 123 million accounts in microfinance and commercial banks (15.1 million of these accounts are held by microfinance banks). Total number of BVNs registered as at December 2018 was 36.2 million out of which 14.9 million were owned by female (18 years and above). Despite an increase in the number of savings accounts, the 2018 target (of $52.8 \%$; 53,5m adults) was missed.

\subsubsection{Access to Credit}

From the industry data, the total number of credit accounts recorded in 2018 was 5.43 million (accounts) made up of 1.7 million accounts in Deposit Money Banks (DMBs) and 3.72 million accounts in Microfinance Banks (MFBs). This is estimated to be about $5.5 \%$ of total adult population; this is far below the $34.4 \%$ credit target for 2018 . The lack of access to credit remains a huge barrier for many entrepreneurs looking to grow their businesses sustainably.

\subsubsection{Insurance}

Insurance penetration remains significantly subpar, as only $2 \%$ of the Nigerian adult population had access to insurance compared to a target of $32.4 \%$ for 2018

\subsubsection{Pension}

In the period under review, the number of Nigerians contributing to a Pension scheme supervised by the National Pension Commission, stood at 8.47 million representing $8.5 \%$ of the adult population compared to the target of $32.4 \%$ for 2018 .

\subsection{Channels}

\subsubsection{DMB Branches}

As at December 2018, the total number of Commercial Banks stood at 24, one less than the corresponding period of the preceding year. The total number of active branches was 
4,752 in 2018 up from 4,763 in 2017; the number of cash centres remained 712 in 2018 from 686 in the previous year. According to the EFInA [15], there were 5.3 bank branches per 100,000 adults compared with a target of 7.5 per 100,000 adults for 2018 .

\subsubsection{MFB Branches}

As at December 2018, the number of Microfinance Banks decreased to 898 from 1,002 in December 2017. Similarly, the total number of MFB branches also decreased from 2,271 in December 2017 to 2,044 in December 2018. The number of MFB branches per 100,000 adults in 2018 stood at 2.0 as opposed to a target 4.7 per 100,000 adults for 2018 . It is noted however that the advent of digital financial services (DFS) with a cashless economy provides the impetus for deemphasizing the increase in the number of bank branches.

\subsubsection{ATMs}

As at December 2018, the number of ATMs deployed across the country in absolute terms stood at 18,615; however, this achievement represents only $34.7 \%$ per cent of the 2018 target of 52.9 ATMs per 100,000 adults.

\subsubsection{POS}

As at December 2018, the number of POS devices connected were 217,283 , but only 144,461 of these were active representing 214.4 POS per 100,000 adults compared with 605.6 per 100,000 adults targeted for 2018 .

\subsubsection{Agents}

In absolute terms, the number of Mobile Money agents surged from 11,104 in 2017 to 38,416 in 2018, representing 246 per cent increase. About 18 per cent of these agents are located in 2 States (Lagos \& Kano) and the FCT. For 2018, the number of bank agents per 100,000 adults was 38.6 compared with 43.4 targeted for the same year.

\subsection{Enablers}

\subsubsection{Know Your Customer (KYC) ID}

The total number of adults issued with a National Identity Number (NIN) as at December 2018 stood at 33.7million. Of these, only 1,609,443 were issued e-IDs representing $4.78 \%$ of registered NIN holders. Issuance with e-ID provides a valid form of identification for the provision of financial services. To this end, the NIMC (government agency responsible for issuing e-ID) has been mandated to register all Nigerians and legal residents or at least 95 per cent by the year 2022 .

\subsubsection{Financial Literacy}

The delivery of financial education remains critical to improving financial literacy of unbanked populations in order to empower them with the capabilities to make informed decisions. One key outlook for financial literacy is the digitization of procedures to enable financial educators and trainers' access e-content to be used to train end beneficiaries. As at end 2018, 3,894 Volunteer National Youth Service Corps (NYSC) members were trained across 16 states to provide end-beneficiary financial education to rural communities in their respective states; the 98,800 new bank accounts opened within the year were attributed to the CBN's financial literacy programme.

\subsubsection{Women Initiatives}

The Gender Gap persisted with financial access skewed towards the male than female adults. In 2018 the financial exclusion rate for women stood at 40.9 per cent $(20.5$ million) as against 32.5 per cent (16.2 million) for men [15]. This means that the financial inclusion gender gap in Nigeria stood at 8.4 per cent as at 2018 .

\subsubsection{Youth Initiatives}

The youth (aged 18-25) group is the least financially included age group; $47 \%$ of the youth are excluded [15].

Actual outcomes as summarised above did not meet expectations across all inclusion targets for products, channels and enablers At this rate, Nigeria will continue to be ranked low in every indicator of financial inclusion as observed by Demirguc-Kunt and Klapper [32] and the [1]. Indeed, 36.6 million (36.8\%) adult Nigerians are financially excluded [15]. Although the Nigerian government through the $\mathrm{CBN}$ and other regulators often claim to have done much to capture more Nigerians into the financial ecosystem especially in rural areas, the reality on the ground shows that much needs to be done if the nation is to meet its 2020 targets.

\section{Financial Inclusion Issues in Nigeria}

Why has Nigeria failed to meet its 2018 financial inclusion targets? What are the issues and challenges of financial inclusion in Nigeria? The paper explores historical, sociocultural, political and economic issues peculiar to Nigeria that may have adversely impacted financial inclusion in Nigeria. Historically, Nigerians worked in the cash-based informal sector [46]. This point is re-echoed by Financial Inclusion Insights (FII) [47] finding that 47 percent of Nigerians generated income solely through employment in the irregular informal sector (http://finclusion.org/country/africa/nigeria). To draw these cash holders away from informal money management, formal financial services must better match their typical transaction sizes, needs and their unique sense of what constitutes financial value-added, a proposition not very popular with financial providers

The majority of the Nigerian population is poor, despite the wealth in the country; sixty percent of Nigerians live below the poverty line. Approximately $20 \%$ of the population owns $65 \%$ of the national wealth; the benefits of the wealth generated by oil production are not distributed among the Nigerian population. The poor rarely feel poverty reduction measures; the decentralised nature of the political system means state expenditure on pro-poor activities is most often subject to political will. Also, the poor lack financial sophistication due to their generally low level of financial literacy. Majority of the estimated 40 million financially 
excluded Nigerians lack knowledge of the available services and benefits derivable from accessing financial these services; staff of the financial service providers often display lack of adequate understanding of how the services they provide contribute to the global financial inclusion agenda and so are unable to educate their customers effectively. Indeed, sub-optimal outcomes from attempts to increase customer awareness are reflected in the lack of appreciable progress in the literacy level of the populace. This has remained a major impediment to the progress of the financial inclusion as a result.

Financial access in Nigeria has traditionally been led by banks. However, several factors have contributed to a slowdown in bank account ownership and use, including (i) inability to access the necessary documentation such as drivers' licence, international passport, national identity card, and electricity bill to open a bank account. Most of these documents are not easily accessed by low income earners, including those who earn income from the cash-based informal economy [51]; (ii) the crisis in the banking industry during the 1990s which eroded the confidence of Nigerians in the industry; the distrust of banks persists to this day; (iii) excessive spending by the political class has led to an increase in level of currency outside the banking system. The ratio of currency outside the banking system moved up to 47.7 per cent by end of the 1990s [46]; (iv) government policies that have actually increased the cost of transactions associated with bank-based financial services can actually discourage financial inclusion; e.g., government imposed a stamp duty of at least $\$ 50$ on bank customers for money received into their accounts, and added charges on cash withdrawals, debit card issuances and online transfers. The rise in costs associated with bank-based financial services lower the appeal of banks among the population [47]; (v) consequent upon the requirement for bank account holders to obtain biometric bank verification numbers (BVNs), some accounts were closed due to noncompliance and some customers have faced difficulties linking their BVN to their accounts; and (vi) several concerns have been expressed about the trustworthiness of Nigerian banks including, transparency of banks in implementing prescribed financial guidelines, perceived inefficient e-channel services of most of the deposit money banks and perceived inadequate cyber security [48].

More recently, critical challenges have confronted Nigeria: a worsening cycle of violence between largely Christian farming communities and predominantly Muslim pastoralists, most of who are ethnic Fulani (www.sfcg.org), terrorism, kidnapping and human trafficking, mass killings and an overwhelming number of internally displaced persons (IDPs) hosted in camps. The United Nations Special Rapporteur for Extrajudicial, Summary or Arbitrary Executions [49] drew attention to the following challenges confronting Nigeria:

Weak rule of law and its brewing crisis are intertwined with, result from, and come on top of: a nation-wide population explosion and increased rates of extreme poverty which characterises the reality for roughly half of the
Nigerian population. This is exacerbated by the spreading environmental degradation and desertification evident throughout West Africa. It is also fed by the increasing proliferation of small and military-grade weapons made readily available as a result of regional instability and originating, according to some reports, from as far north as the Libyan conflicts (p2).

These nation-wide and broader regional pressures applied against Nigeria's diverse political-economic systems are producing localised systems and country-wide patterns of violence, many of which are seemingly spinning out of control. They are claiming the lives of thousands and include, for instance, arbitrary killings in the context of: (i) the military conflict in the North of the country, against Boko Haram and splinter groups; (ii) the conflict in the Middle Belt region of Nigeria, along with some parts in the North West and the South, between Fulani herdsmen and farming communities belonging to various ethnic groups; (iii) cultism in the oil-producing Southern States and other well-organised criminal gangs; (iv) local militias engaged in mining and cattle rustling in the North West, particularly Zamfara State; (v) the repression of the Indigenous People of Biafra (IPOB), the Islamic Movement of Nigeria (IMN), and the Movement for the Survival of the Ogoni People (MOSOP) and (vi) the mass expulsion of slum dwellers in Lagos and elsewhere and more generally greed motivated policies and interventions resulting in random killings.

These issues and challenges as highlighted above have placed compelling constraints to achieving the 2018 financial inclusion targets. As articulated by Nalini and Mariappan [50], economic growth is an objective of financial inclusion which includes political, economic and social inclusion. The exclusion of any person or group of people from these three dimensions of inclusion, for example, arising from the critical challenges confronting Nigeria, will exacerbate financial exclusion because the political, economic and social life of people are interwoven and the three dimensions are required to attain financial inclusion. Where the majority are excluded from the financial system, the gain of economic development does not reach every one and this leads to inequality. Hence, inclusive growth is needed in an economy in order to share the benefits of economic growth more or less equally among all sections of people [52] which may be a mirage where a significant proportion of the population not part of the financial system [51].

\section{Summary and Recommendations}

Findings in the study are that the 2018 financial targets have not been met, suggesting that the 2020 targets will be missed too. Critical issues and challenges confronting the country have been identified; these have combined to limit achievement of significant expansion in the level of financial inclusion in Nigeria. These issues and challenges need to be addressed. In particular, the populace require to be taught financial education. Financial education is considered one of the most significant variables in successful implementation 
of financial inclusion [53]. Effective financial education provides clients with knowledge of products offered by the banking sector, as well as insight into the processes necessary to be part of the system. With financial education, even potential clients with small amounts of savings or financial resources would have possessed enough knowledge to participate in the financial system enabling the purchase of financial products. Given that agriculture is the largest sector of the economy employing more than $75 \%$ of the population, financial inclusion policies should focus on initiatives tied to agriculture and rural dwellers.

\section{References}

[1] World Bank (2013). Universal financial access is vital to reducing poverty, innovation key to overcoming the enormous challenge. President Jim Yong Kim Press release http://www.worldbank.org/en/news/press-

release/2013/10/11/universal-financial-access-vital-reducingpoverty-innovation-jim-yong-kim.

[2] Kostov P · Arun T \& Annim S. (2015). Access to financial services: The case of the 'Mzansi' account in South Africa. Review of Development Finance 5 (1): 34-42.

[3] Kumar, Beck, Campos, \& Chattopadhyay (2005). Assessing financial assess in Brazil. World Bank Working Paper no. 50.

[4] Christopoulos, T., Farias, L., Marques, T. (2015). Evaluating Banking Agents: The case of Brazilian Correspondents $D L S U$ Business \& Economics Review 24 (2): 92-107.

[5] Dubus, A. \& Hove. L. (2017). M-PESA and financial inclusion in Kenya: of paying comes saving? https://hal.archives-ouvertes.fr/hal-01591200.

[6] McKinsey Global Institute. (2016). Digital finance for all: Powering inclusive growth in emerging economies (pp. 1124). McKinsey Global Institute.

[7] Beck, T., Demirgüç-Kunt, A. \& Levine, R. (2007). Finance, Inequality and the Poor; Journal of Economic Growth, 12 (1), 27-49.

[8] Cull, R. Ehrbeck, T. \& Holle. N. (2014). Financial Inclusion and Development: Recent Impact Evidence. Focus Note 92. $\begin{array}{llll}\text { Washington, } & \text { D. } & \text { C.: } & \text { CGAP. }\end{array}$ https://www.cgap.org/sites/default/files/FocusNote.

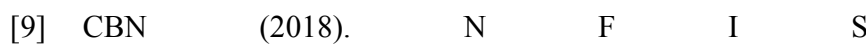
https://www.cbn.gov.ng/out/2019/ccd/national\%20financial\% 20 inclusion $\% 20$ strategy.pdf.

[10] Humphrey, D., \& Berger, A. (1990). Market failure and resource under economic incentives to use different payment instruments In: D. Humphrey (Eds.), The U. S. payment system: Efficiency, risk and the role of the Federal Reserve Bank. Academic Publisher, Boston.

[11] Humphrey, D., Lawrence, B. \&Vessala, J. M. (1996). Cash, electronic payments: a cross-country analysis. Journal of Money, 28: 914-939.

[12] Klee, E. (2004). Paper or Plastic: The Effect of Time on Check and Debit Card Use at Grocery Stores. http://ssrn.com/abstract=687159.
[13] Garcia-Swartz, D.; Hahn, W. \& Layne-Farrar, A. (2007). Further thoughts on the cashless society: A reply to Dr. Shampine, Review of Network Economics, 6 (4), 509-524.

[14] Khan, J., \& Craig-Lees, M. (2009). Cashless Transactions: Perception of money in mobile payments. International Business and Economic Review, 1 (1), 23-32.

[15] EFInA, (2018). EFInA access to financial services in Nigeria. https://www.efina.org.ng/wp-content/uploads/2019/01/A2F2018-Key-Findings-11_01_19.pdf.

[16] Jonker, N. (2005). Payment Instruments as perceived by Consumers-a Public Survey. De Nederlandsche Bank Working Paper.

[17] Gangopadhayay, S. (2009). How can Technology Facilitate Financial Inclusion in India? A discussion paper. Review of Market Integration, 1 (2): 223-256.

[18] Mas, I. (2012). Payment in Developing Countries: Breaking Physical and Psychological Barriers Transaction World Magazine. http://ssrn.com/abstract=2189989.

[19] Ebiringa, O. T. (2010). Automated Teller Machine and Electronic Payment System in Nigeria: A synthesis of the critical success factors. Journal of Sustainable Development in Africa, 1 (12), 71-86.

[20] Kodan, A. S. K., \& Chhikara, K. S. (2013). A Theoretical and Quantitative Analysis of Financial Inclusion and Economic Growth. Management and Labour Studies, 38 (1-2), 103-133. Doi: $10.1177 / 0258042 \times 13498009$.

[21] Midgley, J. (2005). Financial inclusion, universal banking and post offices in Britain Area, 37 (3): 277-285. https://doi.org/10.1111/j.1475-4762.2005.00631.x.

[22] Bernad, C., Fuentelsaz, L., \& Gómez, J. (2008) Deregulation and its long-run effects on the availability of banking services in low-income communities. Environment and Planning A, 40 (7) 16811696. https://doi.org/10.1068/a39222.

[23] Marshall, J. N. (2004). Financial institutions in disadvantaged areas: a comparative analysis of policies encouraging financial inclusion in Britain and the United States. Environment and Planning A, 36 (2), 241-261. https://doi.org/10.1068/a3664.

[24] Chibba, M. (2009). Financial inclusion, poverty reduction and the Millennium Development Goals. European Journal of Development Research, 21 (2), 213-230. https://doi.org/10.1057/ejdr.2008.17.

[25] Wahiba, N. F., \& Weriemmi, M. E. (2014). The Relationship between Economic Growth and Income Inequality International Journal of Economics and Financial Issues, 4 (1): 135-143.

[26] Mehrotra, N., Puhazhendhi, V., Nair G. \& Sahoo, B. B. (2009). Financial inclusion: an Overview. Department of Economic Analysis and Research, National Bank for Agriculture and Rural Development (NABARD), Occasional Paper 48, Mumbai.

[27] Buckland, J. (2012). Hard choices: Financial exclusion, fringe banks, and poverty in urban Canada. University of Toronto Press.

[28] Stiglitz, J. E., \& Weiss, A. (1981). Credit rationing in markets with imperfect information. The American Economic Review, $71(3), 393-410$. 
[29] Dymski, G. (2005). Financial globalization, social exclusion and financial crisis. International Review of Applied Economics, 19 (4).

[30] Buckland, J. \& Martin, T. (2005) Two-Tier Banking: The Rise of Fringe Banks in Winnipeg's Inner-city,' Canadian Journal of Urban Research, 14 (1): 158-181.

[31] Andrianaivo, M and Kpodar, K (2011). ICT, Financial Inclusion, and Growth: Evidence from African Countries. IMF Working Paper WP/11/73.

[32] Demirgüc-Kunt, A., \& Klapper, L. (2012). Financial Inclusion in Africa: An Overview. The World Bank: Policy Research Working Paper 6088.

[33] Balach R, Law SH, Habibullah MS (2016). The Role of Financial Inclusion in financial development: International evidence. Abasyn Journal of Social Sciences, 9: 330-344.

[34] Zins, A. \& Weill, L. (2016). The determinants of financial inclusion in Africa. Rev. Dev. Finance http://dx.doi.org/10.1016/j.rdf.2016.05.001.

[35] Inoue, T. \& Hamori, S. (2016). Financial access and economic growth: Evidence from Sub-Saharan Africa. Emerging Markets Financial Trends; 52: 743-753.

[36] Kim, J. H., (2016) A study on the effect of financial inclusion on the relationship between income inequality and economic growth. Emerging Market Finance and Trade 52 (2): 498-512.

[37] Kim, D., Yu, J., \& Hassan, M. (2018). Financial inclusion and economic growth in OIC countries. Research in International Business and Finance, 43, 1-14.

[38] Sethi, D. \& Acharya, D. (2018), "Financial inclusion and economic growth linkage: some cross country evidence", Journal of Financial Economic Policy, 10 (3): 369-385. https://doi.org/10.1108/JFEP-11-2016-0073.

[39] Aduda, J. \& Kalunda, E. (2012) Financial Inclusion and Financial Sector Stability with reference to Kenya: A Review of Literature. Journal of Applied Finance \& Banking, 2 (6): 95-120.

[40] Migap, J., Okwanya I. \& Ojeka, G. (2015). Financial Inclusion for Inclusive Growth: The Nigerian Perspective. International Journal of Information Technology and Business Management, 37 (1): 1-8.

[41] Babajide, A, Adegboye F, \& Omankhanlen, A (2015). Financial inclusion and economic growth in Nigeria.
International Journal of Economics and Financial Issues, 5 (3): 629-637.

[42] Omojolaibi J (2017) Financial Inclusion, governance and economic progress in Nigeria: What happens to the welfare of the poor? Arabian Journal of Business and Management Review 6 (7): 72-85.

[43] World Bank (2018). The Little Data Book on Financial Inclusion. World Bank, Washington, DC. (C) World Bank. https://openknowledge.worldbank.org/handle/10986/29654.

[44] Interswitch Financial Inclusion Services (2018) https://www.interswitchgroup.com.

[45] NIBSS (2018) Annual Report https://nibss-plc.com.ng/.

[46] Kama, U. \& Adigun, M. (2013) Financial Inclusion in Nigeria: Issues and Challenges, Central Bank of Nigeria Occasional Paper No. 45.

[47] Financial Inclusion Insights (FII) http://finclusion.org/country/africa/nigeria.html.

[48] Ibor, B., Offiong, A. \& Mendie, E (2017). "Financial Inclusion and Performance of Micro, Small and Medium Scale Enterprises in Nigeria." International Journal of Research $\begin{array}{llll}\text { Granthaalayah, } & 5 & \text { (3), }\end{array}$ https://doi.org/10.5281/zenodo.439557.

[49] The United Nations Special Rapporteur for Extrajudicial, Summary or Arbitrary Executions (2019) https://reliefweb.int/report/nigeria/end-visit-statement-specialrapporteur-extrajudicial-summary-or-arbitrary-executions.

[50] Nalini, G. S., \& Mariappan, K. M. (2012). Role of banks in financial inclusionResearch Journal of Commerce \& Behavioural Science 1 (4): 33-36.

[51] Aina, S \& Oluyombo, O. (2014). The Economy of Financial Inclusion in Nigeria: Theory, Practice and Policy. CIBN $\begin{array}{lllll}\text { Occasional Papers } & \text { Series. } & 1 & \text { (1): } & \text { i-32. }\end{array}$ https://ssrn.com/abstract=2885306 http://dx.doi.org/10.2139/ssrn.2885306.

[52] Uma, H. R., Rupa, K. N., \& Madhu, G. R. (2013). Impact of bank led financial inclusion model on the socio-economic status of Saral saving account Holders. Indian Journal of Research; 2 (9), 50-52.

[53] Thoene, U. \& Turriago-Hoyos, A. (2017) Financial Inclusion in Columbia: A scoping literature review; Intangible Capital: https://doi.org/10.3926/ic.946. 